\title{
PENGARUH PENGGUNAAN TEPUNG TAPIOKA DALAM PEMBUATAN LEM TEGEL KARET
}

\section{THE EFFECT OF USING TAPIOCA FLOUR TO PRODUCE GLUE FOR TILE RUBBER}

\author{
Nesi Susilawati dan Rahmaniar \\ Balai Riset dan Standardisasi Industri Palembang \\ Jl. Perindustrian II No. 12 Km. 9 Sukarami, Palembang \\ e-mail: nesithree@gmail.com
}

Diterima: 16 Oktober 2017; Direvisi : 13 Desember 2017 - 21 Juni 2018; Disetujui: 28 Juni 2018

\begin{abstract}
Abstrak
Penelitian ini bertujuan untuk mengetahui pengaruh penambahan tepung tapioka sebagai bahan pengisi terhadap karakteristik fisik lem tegel karet yang meliputi daya rekat dan viskositas. Lem tegel karet dibuat dari campuran tepung tapioka sebagai bahan pengisi. Rancangan percobaan dengan variasi perbandingan tepung tapioka yaitu formula $\mathrm{A}$ (tepung tapioka $8 \mathrm{~g}$ ), formula B (tepung tapioka $12 \mathrm{~g}$ ), formula $\mathrm{C}$ (tepung tapioka $16 \mathrm{~g}$ ), formula D (tepung tepioka $20 \mathrm{~g}$ ), formula $\mathrm{E}$ (tepung tapioka $24 \mathrm{~g}$ ) dan $\mathrm{F}$ (pembanding/lem dipasaran). Hasil penelitian menunjukkan bahwa penambahan tepung tapioka sebagai bahan pengisi pada pembuatan lem tegel karet berpengaruh terhadap daya rekat dan viskositas dalam hal keteguhan rekat dan nilai viskositas. Semakin tinggi penambahan tepung tapioka $(24 \mathrm{~g})$, maka daya rekat akan semakin rendah (1,78 kg/in) akibat penurunan gaya adhesinya. Formula lem tegel karet yang mendekati hasil uji lem karet yang ada dipasaran (nilai daya rekat yaitu 4,395 kg/in dan nilai viskositas Brookfield yaitu 98,275 cP) adalah formula B (tepung tapioka $12 \mathrm{~g}$ ) dengan nilai daya rekat $4,17 \mathrm{~kg} / \mathrm{in}$ dan nilai viskositas $51,33 \mathrm{cP}$.
\end{abstract}

Kata kunci : Lem tegel karet, tepung tapioka, white crepe

\begin{abstract}
The purpose of this research is to know effect the addition of tapioca flour to adhesiveness and viscosity of the tile compound rubber glue formulations using filler material. The tile compound rubber glue made from mixture of tapioca flour as filler material. Design research with variation of tapioca flour such as formula $A$ (8 $g$ of tapioca flour), formula $B$ (12 $\mathrm{g}$ of tapioca flour), formula $C$ (16 g of tapioca flour), formula $D$ (20 $\mathrm{g}$ of tapioca flour) and formula $E$ (24 g tapioca flour) and $F$ (requirements generally and comparison glue). The result showed that the addition of tapioca flour have significant effects on the adhesiveness and viscosity of glue. The higher the addition of tapioca flour $(24 \mathrm{~g})$, the adhesiveness would be lower (1.78 $\mathrm{kg} / \mathrm{in})$ because of decreased adhesion force. Tiles rubber compound glue formula complied with requirements generally glue (the adhesiveness value of $4.395 \mathrm{~kg} /$ in and the Brookfield viscosity value of $98.275 \mathrm{cP}$ is the $B$ formula (tapioca flour $12 \mathrm{~g}$ ) with an adhesiveness value of $4.17 \mathrm{~kg} /$ in and viscosity value $51.33 \mathrm{cP}$.
\end{abstract}

Keywords : Tapioca flour, tiles rubber compound glue, white crepe

\section{PENDAHULUAN}

Lem adalah suatu bahan yang berfungsi sebagai obyek perantara untuk merekatkan bahan satu dengan yang lain. Bahan- bahan kimia yang digunakan sebagai bahan dasar pembuat lem adalah termasuk bahan makromolekul (Hartono et al, 1997). Cara kerja lem adalah liquid solidification yaitu dengan cara melelehkan makromolekul diatas titik leburnya. Setelah dingin mereka mempunyai kuat rekat yang tinggi (Cagle, 1982).
Menurut Julian (2016), Adhesive atau lem adalah zat atau bahan perekat yang digunakan untuk menyatukan dua bagian (sisi) suatu benda. Secara garis besar material pembentuk lem terbuat dari bahan alami maupun bahan sintetis. Lem yang terbuat dari bahan alami biasanya menggunakan campuran air sebagai pelarutnya sehingga kekuatannya akan melemah ketika terkena air akan tetapi jenis lem ini tidak mudah terbakar. Sedangkan lem sintetis menggunakan pelarut kimia dan lem akan mengering setelah pelarutnya 
menguap akan tetapi jenis lem ini sangat mudah terbakar.

Penelitian yang pernah dilakukan diantaranya, pembuatan lem sintetik yang menggunakan bahan baku chloroprene rubber baypren grade 300, dimana lem sintetik yang dihasilkan didapat formula yang baik dengan menggunakan chloroprene rubber $100 \mathrm{phr}$, lem sintetik ini mempunyai kuat rekat lebih tinggi dibandingkan dengan lem yang ada dipasaran (Yuniari, 2008)..

Penelitian lem menggunakan bahan baku non minyak bumi dilakukan oleh Herminiwati et al. (2008) menggunakan Natural Rubber (NR) dalam pembuatan lem kompon karet untuk sepatu kulit yang dibuat dengan proses vulkanisasi. Lem ini mempunyai kuat rekat sol dalam dan sol luar $1553 \mathrm{~g} / \mathrm{cm} \quad(3,945 \mathrm{~kg} / \mathrm{in})$ yang memenuhi syarat JIS S 5050, 1984 untuk sepatu kulit dan nilai viskositas $2250 \mathrm{cP}$. Susanto dan Nurhayati, (2017) menggunakan lateks karet alam pekat sistem dadih dan di depolimerisasi, sehingga didapat kualitas lem karet berkisar antara 4,76-17,25 kg/in dan viscositas brookfield 1966-3810 cP.

Penelitian pembuatan lem tegel karet untuk mengetahui pengaruh penggunaan tepung tapioka terhadap daya rekat dan viskositas. Pembuatan lem tegel karet menggunakan campuran karet alam dengan jenis white crepe, variasi tepung tapioka dan bahan-bahan kimia.

Karet alam merupakan polimer yang bersifat elastis, sehingga sering disebut elastomer, jenis karet alam diantaranya karet alam konvensional (white crepe) dibuat dari lateks kebun, yang digumpalkan, kemudian digiling menjadi lembaran-lembaran yang tipis. Karet alam merupakan polimer isoprene, tersusun dari hidrokarbon karet dan senyawa nonkaret. Beberapa senyawa non-karet adalah protein, karbohidrat, lipid, karoten, glikopid, mineral, enzim, fosfolipid dan berbagai bahan lain (Daik, et al., 2007 ; Masyrukan dan Alfian, 2013)

Karet alam dikenal sebagai karet lunak, memiliki berat molekul yang rendah, mempunyai daya lekat yang baik, sehingga karet alam dapat dijadikan dasar dalam industri perekat berbahan lateks (Lee, 1997; Chen et al., 2007). Karet alam mempunyai kelemahan tidak tahan oksidasi, panas dan minyak (Lee, 1997), hal ini dikarenakan karet alam memiliki ikatan rangkap yang mudah teroksidasi atau mengadisi gugus lain pada rantai molekul monomernya (Palupi, et al. 2008), dengan melakukan modifikasi struktur molekul pada karet alam dapat mengatasi hal tersebut.

Pada pembuatan lem, karet alam ditambahkan dengan beberapa jenis bahan kimia, agar diperoleh lem sesuai lem yang ada dipasaran, yaitu bahan perekat (gondorukem/siongka) dan bahan pelarut (toluene).

Gondorukem(Resina colophium) adalah hasil olahan destilasi uap getah sadapan batang pinus (oleoresin) selain minyak terpentin. Gondorukem berbentuk padatan berwarna kuning kecoklatan, sedangkan minyak terpentin berwujud cairan putih bening. Gondorukem merupakan asam organik alkyl tricyclic tak jenuh yang berasal dari derivat alam. Komponen senyawa utama dari gondurukem adalah asam abietat dan asam pimarat yang memiliki sifat amfipatik yaitu mempunyai gugus karboksil yang bersifat hidrofilik dan molekul tricyclic yang bersifat hidrofobik (Wiyono, 2009; Khadafi et al., 2014).

Gondorukem adalah campuran asam-asam resin antara lain berbagai isomer dari anhidrida asam abietat $\mathrm{C}_{19} \mathrm{H}_{29} \mathrm{COOH}$, abietat anhidrida $\mathrm{C}_{40} \mathrm{H}_{58} \mathrm{O}_{3}$, dan hidrokarbon (zat tak tersabun) yang diperoleh dari hasil pengolahan getah pinus yang berupa padatan. Gondorukem merupakan senyawa kompleks yang larut dalam pelarut organik seperti etil alkohol, etil ester dan benzena namun tidak larut dalam air. Gondorukem getah dan gondorukem kayu terdiri dari 80-90\% asam resin dan sekitar $10 \%$ komponen netral, sedangkan gondorukem tall oil terdiri dari $30-60 \%$ asam resin, 30\% asam lemak, dan sekitar 10\% komponen netral. (Priyosetyoko, 2012).

Gondorukem merupakan salah satu bahan yang digunakan untuk campuran produksi ban, campuran batik tulis dan cetak, cat dan plasticizers. (Darmawan, et. al, 2000). Gondorukem digunakan pula sebagai bahan perekat yang berfungsi sebagai tackifier, pemacu perekatan (adhesion 
promoter) atau pemacu kekentalan (viscosity promoters) untuk memperbaiki sifat-sifat produk akhir (Coppen et al., 1995, Khadafi et al., 2014).

Dalam penelitian ini, gondorukem berfungsi untuk memperkuat daya rekat lem, pembuatan lem tegel karet digunakan pelarut yaitu toluene, yang merupakan hidrokarbon aromatic.

Pelarut merupakan cairan yang digunakan untuk mengencerkan atau menyebarkan bahan dasar (base) dan bahan-bahan aditif dalam campuran untuk menghasilkan bentuk cair untuk kemudahan dan kesempurnaan pencampuran. Semua pelarut ini akan hilang pada proses pengeringan perekat.

Tepung tapioka dapat dimanfaatkan sebagai bahan pengisi, pengental, dan bahan pengikat, karena mempunyai daya rekat yang tinggi. Tepung tapioka merupakan bahan pengisi ramah lingkungan dan dapat dimanfaatkan sebagai bahan pengisi dalam pembuatan lem tegel karet, sehingga dilakukan penelitian untuk memanfaatkan tepung tapioka sebagai bahan pengisi dalam pembuatan lem tegel karet.

Beberapa faktor yang mendukung proses pengeleman yaitu sifat kekerasan dari solid surface, kekuatan mekanik, pemanasan dan penekanan, perlakuan permukaan (surface treatment), sehingga menghasilkan daya rekat yang lebih baik (Brian, 1992; Herminawati et al, 2008).

\section{BAHAN DAN METODE}

Kegiatan penelitian dilaksanakan di Laboratorium Balai Riset dan Standardisasi Industri Palembang.

\section{A. Bahan dan Alat}

Bahan-bahan yang digunakan dalam penelitian ini terdiri dari bahan baku dan bahan pembantu, yaitu White Crepe, Toluene, Gondorukem, dan bahan pengisi tepung tapioka.

Peralatan yang digunakan terdiri dari open mill, timbangan, kompor, baskom/panci, pengaduk, botol kemasan dan viskometer brookfield.

\section{B. Metode yang digunakan}

Pada penelitian ini faktor yang dipelajari meliputi pengaruh penambahan bahan pengisi tepung tapioka. Adapun variasi penambahan tepung tapioka dapat dilihat pada tabel 1.

Tabel 1. Formula lem tegel karet

\begin{tabular}{llrrrrr}
\hline \multirow{2}{*}{ No } & $\begin{array}{l}\text { Nama Bahan/ } \\
\text { satuan }\end{array}$ & \multicolumn{6}{c}{ Formula } \\
\cline { 2 - 7 } 1 & $\begin{array}{l}\text { White crepe } \\
\text { (gr) }\end{array}$ & 80 & 80 & 80 & 80 & 80 \\
2 & $\begin{array}{l}\text { Tepung } \\
\text { Tapioka } \\
\text { (gr) }\end{array}$ & 8 & 12 & 16 & 20 & 24 \\
3 & $\begin{array}{l}\text { Gondorukem } \\
\text { (gr) }\end{array}$ & 8 & 8 & 8 & 8 & 8 \\
4 & $\begin{array}{l}\text { Toluene } \\
(\mathrm{cc})\end{array}$ & 300 & 300 & 300 & 300 & 300 \\
\hline
\end{tabular}

\section{PROSEDUR KERJA Penimbangan}

Bahan yang diperlukan untuk masing-masing perlakuan ditimbang sesuai formula.

\section{Pencampuran (mixing)}

Proses pencampuran dilakukan dalam gilingan terbuka (Open Mill)). Selanjutnya dilakukan proses mastikasi white crepe selama 1-3 menit.

- Kemudian dilakukan pencampuran dengan tepung tapioka sesuai perlakuan selama lebih kurang $3-8$ menit.

- Keluarkan lembaran kompon dari open mill dan letakkan kompon di atas plastik transparan dan potong kecil-kecil.

- Kemudian masukkan dalam wadah/botol, tambahkan gondorukem yang sudah dihancurkan dan tambahkan toluene.

- Lalu diamkan selama 1-3 hari dan lakukan pengadukan. Prosedur ini dilakukan untuk formula $A$ sampai formula $E$

Formula A sampai dengan formula E dibandingkan dengan lem yang ada dipasaran sebagai kontrol $(F)$. 
PEUBAH YANG DIAMATI

Peubah yang diamati dalam penelitian ini, meliputi daya rekat dan viskositas lem tegel karet.

\section{HASIL DAN PEMBAHASAN}

\section{Daya rekat (Adhesive)}

Menurut Saleh et al (1995), persentase kerusakan bahan merupakan salah satu kriteria penilaian mutu perekat dan perekatan. Terjadinya penurunan perekatan dapat disebabkan dari seluruh bidang perekatan atau permukaan yang direkat tidak mencapai perekatan yang sempurna karena bagian-bagian yang tidak mengalami kerusakan mempunyai kekuatan ikatan yang lebih lemah dari pada kekuatan geser bahan. Hasil pengujian daya rekat lem tegel karet dapat dilihat pada Gambar 1.

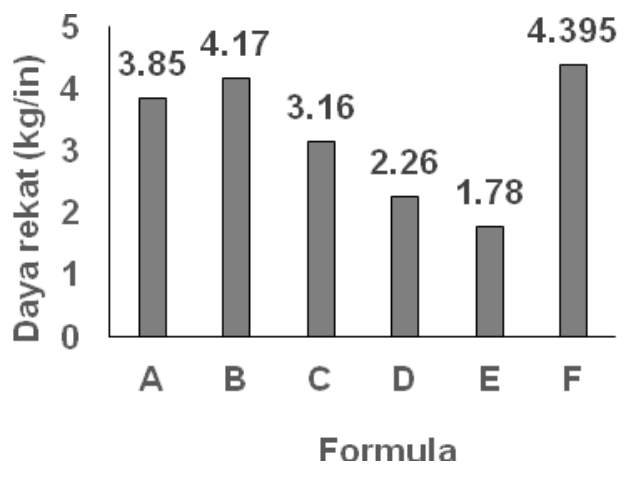

Gambar 1. Pengaruh penambahan tepung tapioka terhadap daya rekat lem tegel karet

Gambar 1 menunjukkan bahwa nilai daya rekat lem tegel karet yang mendekati daya rekat lem dipasaran adalah pada formula $\mathrm{B}$ (tepung tapioka $12 \mathrm{~g})$ yaitu $4,17 \mathrm{~kg} / \mathrm{in}$, sedangkan nilai daya rekat untuk lem dipasaran (Susanto dan Nurhayati, 2017) yaitu 4,395 kg/in.

Penambahan tepung tapioka tidak berpengaruh secara signifikan terhadap daya rekat. Penambahan tepung tapioka pada pembuatan lem tegel karet dilakukan secara dry mixing sehingga pencampurannya tidak homogen, agar pencampuran produk yang dihasilkan homogen dalam pembuatan lem, maka perlu ditambahkan emulsifier sebagai pengental dan pemantap (Razak dan Apriyanto, 2014).
Penambahan tepung tapioka semakin besar menyebabkan nilai daya rekat semakin kecil, hal ini dikarenakan kandungan tapioka yang lebih banyak juga menyebabkan bahan susah untuk kering sehingga daya rekatnya lemah (Amin et al, 2017).

Peristiwa perekatan tidak terlepas dari adanya pengaruh gaya elektron (Gaya Van der Waals) pada bahanbahan yang saling direkat. Perekatan dapat terjadi karena mengerasnya cairan perekat yang masuk ke dalam struktur bahan yang direkat. Karakteristik perekat peka tekanan adalah sifat kohesifnya yang lebih dominan (Aubrey dan Sherriff, 1980; Shalub et al., 1999).

Menurut Purwadi (1999), proses kerekatan mengakibatkan kerusakan permukaan karena masuknya cairan perekat kedalam pori-pori bahan yang direkatkan dan kemudian mengeras karena proses perekatan mekanis dengan adanya gaya kohesi antara molekul perekat dengan molekul bahan yang direkatkan. Daya rekat merupakan salah satu parameter mutu lem yang penting karena menentukan sifat kekuatan lem..

\section{Viskositas}

Uji viskositas dilakukan untuk mengetahui tingkat kekentalan lem dengan ukuran (cP). Viskositas menggambarkan cepat dan lambatnya cairan lem mengalir. Nilai viskositas pada lem merupakan salah satu faktor penting dalam menentukan kualitas lem karena nilai viskositas mempengaruhi nilai kekuatan rekat.

Nilai viskositas berpengaruh terhadap proses perekatan. Viskositas menunjukkan kemampuan perekat untuk mengalir pada permukaan yang direkat, semakin tinggi viskositas maka kemampuan untuk membasahi dan melakukan penetrasi ke dalam pori-pori permukaan yang akan direkatkan akan semakin sulit. Namun, jika kekentalan terlalu rendah, maka penetrasi perekat ke dalam pori-pori akan berlebihan dan menyebabkan berkurangnya garis rekatan (Ho dan Khew, 1999; Kodama et al., 2003) 
Hasil pengujian viskositas lem tegel karet dapat dilihat pada Gambar 2.

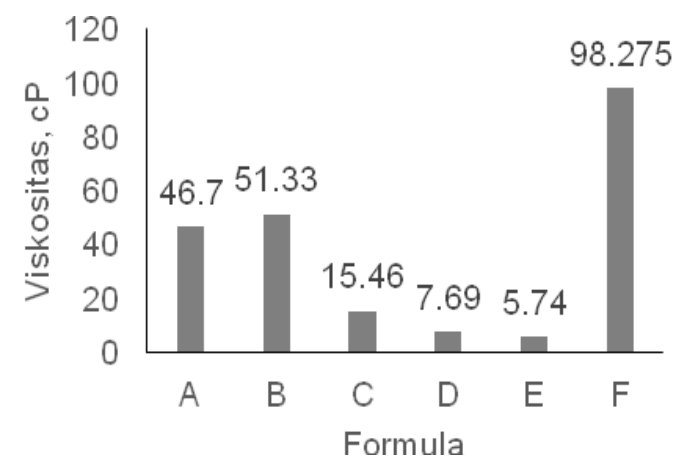

Gambar 2. Pengaruh penambahan tepung tapioka terhadap viskositas lem tegel karet

Gambar 2 menunjukkan bahwa nilai viskositas lem tegel karet yang mendekati viskositas lem dipasaran $(98,275 \mathrm{cP})$ adalah pada perlakuan B (tepung tapioka 12 g) yaitu 51,33 cP. Nilai viskositas semakin kecil dengan penambahan tepung tapioka. Menurut Rahman (2007) semakin tinggi konsentrasi tapioka, viskositasnya semakin rendah, hal ini disebabkan tapioka mengandung amilosa yang tinggi (17,39 \% bk), sesuai pendapat Laga (2006) bahwa semakin tinggi kandungan amilosa menyebabkan kekentalan produk semakin rendah.Menurut Saleh et al (1995), derajat kekentalan suatu lem sangat mempengaruhi cepat lambatnya lem tersebut menyebar pada permukaan yang diolesi lem. Derajat kekentalan sering dimanfaatkan untuk mendeteksi kemudian terserapnya lem kedalam bahan yang direkat. Semakin rendah nilai viskositas lem, semakin cepat lem tersebut merembes kedalam bahan dan membentuk ikatan adhesi antara lem dengan bahan yang direkat.

Nilai viskositas pada lem merupakan salah satu faktor penting dalam menentukan kualitas lem karena nilai viskositas mempengaruhi nilai daya rekat.

\section{KESIMPULAN}

Berdasarkan hasil penelitian, dapat disimpulkan bahwa penggunaan bahan pengisi tepung tapioka memberikan pengaruh yang tidak signifikan pada kualitas lem tegel karet, dalam hal daya rekat dan nilai viskositas.

Penambahan tepung tapioka pada pembuatan lem tegel karet secara dry mixing menyebabkan penurunan nilai daya rekat dan viskositas.

Hasil lem tegel karet yang mendekati lem dipasaran diperoleh pada pelakuan B (tepung tapioka $12 \mathrm{~g}$ ) dengan nilai kekuatan daya rekat yaitu $4,17 \mathrm{~kg} / \mathrm{in}$ dan nilai viskositas yaitu $51,33 \mathrm{cP}$.

\section{SARAN}

Perlu penelitian lanjutan untuk mengetahui pengaruh penggunaan bahan baku dari lateks dengan proses latex compounding terhadap nilai daya rekat dan viskositas.

\section{UCAPAN TERIMA KASIH}

Penulis mengucapkan terima kasih kepada Kepala Baristand Industri Palembang atas dukungan pendanaan dan fasilitas dalam melaksanakan penelitian ini, rekan-rekan tim riset atas selesainya penelitian.

\section{DAFTAR PUSTAKA}

Amin, A.Z, Pramono dan Sunyoto. (2017). Pengaruh Variasi Jumlah Perekat Tepung Tapioka Terhadap Karakteristik Briket Arang Tempurung Kelapa. Jurnal Sain dan Teknologi. Vol 15(2), 111-118.

Aubrey, D., \& Sherriff, M. (1980). Peel adhesion and viscoelasticity of rubber-resin blends. Journal of Polymer Science: polymer chemistry edition, 18(8), 2597-2608.

Brian (1992) dalam Herminiwati, Arum Yuniari dan R. Jaka Susila. Lem Kompon Karet untuk Sepatu kulit yang dibuat dengan Proses Vulkanisasi.

Cagle C.V.,(1982). Hand Book of Adhesive Bonding p 2-1 s/d 2-8. Mc Graw-Hill Book Company, New York.

Chen, L., Gong, X.-I., Jiang, W.-q., Yao, J.j., Deng, H.-x., \& Li, W.-h. (2007). 
Investigation on magnetorheological elastomers based on natural rubber. Journal of Materials Science, 42(14), 5483-5489.

Coppen, J. J. W., Hone, G. A. (1995). Non Wood Forest Product 2. http://www.fao.org. Diakses pada 11 Juni 2018.

Daik, R, Shahinas Bidol and Ibrahim Abdullah, (2007). Effect of Molecular weight on the droplet size and Rheological Properties of Liquid natural Rubber Emulsion. Malaysian Polym J. (MPJ) : 29-38

Darmawan, et.al. (2000). Sari Hasil Penelitian Tusam (Pinus merkusii Jungh. et de Vriese). Badan Penelitian dan Pengembangan Kehutanan dan Perkebunan. Bogor. HIm. 33-35.

Hartono A.J., A Rusdiharsono dan D Hardjanto., (1997), Memahami Polimer dan Perekat. Penerbit Andi Offset Yogyakarta

Herminiwati, Yuniari, A dan Susila R.J. (2008). Lem kompon karet untuk sepatu kulit yang dibuat dengan proses vulkanisasi. Majalah kulit, karet dan plastik. 24(1), 14-18.

Ho, C., \& Khew, M. (1999). Surface morphology of prevulcanized natural rubber latex films by atomic force microscopy: new insight into the prevulcanization mechanism. Langmuir, 15(19), 6208-6219.

Julian Blower, (2016). Praktik Pembuatan adhesive, Pembuatan Lem Berbahan Dasar Dextrin.

Kodama, S., Nishi, K., \& Furukawa, M. (2003). Preparation of low molecular weight natural rubber by ozonolysis of high ammonia latex. Journal of Rubber Research, 6(3), 153-163.

Khadafi, M., Rostika,I., Hidayat,T.(2014). Pengolahan Gondorukem menjadi Bahan Pendarihan sebagai Aditif pada Pembuatan Kertas. Jurnal Selulosa, Vol. 4, No. 1, Juni $2014: 17-24$

Masyrukan, M dan Alfian, A.N (2013). Perbandingan kualitas Rubber Bushing produk Pasaran dengan buatan sendiri. Media mesin Vol 14 No 2 Juli 59-67 ISSN 1411-4348.

Laga, A. 2006. Pengembangan Pati Termodifikasi dari Subtrat Tapioka dengan Optimalisasi Pemotongan Rantai Cabang Menggunakan Enzim Pullunase. Prosiding Seminar Nasional PATPI, 2-3 Agustus 2006,
Perhimpunan Ahli Teknologi Pangan Indonesia (PATPI).

Lee Ks and Whelan A. (1997). Development in rubber technology. Improving product performance. App Sci Pub Ltd, London.

Palupi, N.P, Sailah, I, Syamsu, Y dan Pandji, C. (2008). Karakterisasi perekat siklo karet alam. Jurnal Teknologi Pertanian 4(1). 19-24.

Purwadi, T. 1999. Pengkajian Mutu dan Tekno-Ekonomi Perekat dari Tulang Ikan. [Skripsi]. Program Studi Teknologi Pasca Panen, Institut Pertanian Bogor, Bogor.

Priyosetyoko (2012). Pengujian mutu gondorukem sesuai SNI 7636: 2011. https://priyosetyoko.wordpress.com/2 012/12/23/pengujian-mutugondorukem-sesuai-SNI-7636-2011. Diakses tanggal 12 Juni 2018.

Rahman, A.M. 2007. Mempelajari Karakteristik Kimia dan Fisik Tepung Tapioka dan Mocaf (Modified Cassava Flour) Sebagai Penyalut Kacang Pada Produk Kacang Salut. Skripsi. Fakultas Teknologi Pertanian, IPB. Bogor.

Razak, A dan Apriyanto, M. (2014). Formulasi Tepung Campuran Siap Pakai Berbahan Dasar TapiokaMocaf Dengan Penambahan Maltodektrin Sebagai Tepung Pelapis Keripik Bayam. Jurnal Teknologi Pertanian Vol. 3(1),15-27.

Saleh,M.,R.S. Embun,S, Wijandi dan N. Haq. (1995). Ekstraksi Lem Ikan dari Tulang Ikan Pari. Jurnal Penelitian Perikanan Indonesia, 1 (2):28-38.

Shalub, G. J., Bellinger, G., \& Jackson, J.(1999).Method of bonding with a natural rubber latex and laminate produced: Google Patents.

Susanto,T dan Nurhayati,C. (2017). Pengaruh Temperatur dan Waktu Depolimerisasi Lateks Dadih terhadap Penurunan Berat Molekul dan Mutu Lem Karetnya. Jurnal Dinamika Penelitian Industri Vol. 28 Nomor 1:32-41.

Wiyono, B., (2009). Chemical Treatment on Indonesian Pine Oleoresin and Rosin in Making Fortified Rosin used for Sizing Agent in Paper Making Process. Ehime University, Japan, in press. 
Yuniari, A dan Herminiwati. (2008).

Pembuatan lem sintetik dan

aplikasinya pada alas kaki. Majalah

kulit, karet dan plastik. 24(1). 
